\title{
Can Periodontal Disease Be Considered Linked to Obesity and Lipoinflammation? Mechanisms Involved in the Pathogenesis Occurrence
}

\author{
Vanessa Nicolin ${ }^{1,2}$ (D) Fulvia Costantinides ${ }^{1,2}$ (D) Erica Vettori $^{2}$ (D) Federico Berton $^{1,2}$ (D) Giulio Marchesi $^{2}$ (D) \\ Roberto Rizzo ${ }^{2}$ (iD) $\cdot$ Roberto Di Lenarda ${ }^{1,2}$ (D)
}

Published online: 13 August 2020

(C) The Author(s) 2020

\begin{abstract}
Obesity is a systemic disease, associated with an increased risk of cardiovascular disorders, type 2 diabetes, cancer, asthma, and osteoarthritis. Overweight and obesity have been suggested to be associated with periodontitis as published in studies and narrative summaries. Obesity and periodontal diseases are very prevalent in the world, and both can lead to severe chronic health conditions and impair people's life quality. Knowledge of how immune mechanisms and inflammatory responses are regulated is critical for understanding the pathogenesis of complex diseases, such as periodontitis. In conditions of overweight, it has been demonstrated that approximately $70-80 \%$ of individuals present an adipose tissue turnover that is both structurally and functionally causing of the systemic inflammatory reaction. The objective of this review is to explore the influence of lipoinflammation. The effects of lipoinflammation and obesity on development of periodontal disease are reported together with the exploration of the mechanisms of interaction between these two diseases.
\end{abstract}

Keywords Adipose tissue $\cdot$ Inflammation $\cdot$ Bone remodeling $\cdot$ Periodontal disease $\cdot$ Receptor activator of nuclear factor-kappaB ligand

\section{Introduction}

Obesity is a systemic disease characterized by a fundamental imbalance between the intake of calories/energy and their consumption [1]. In recent decades, there has been an increasing prevalence of obesity with 2.1 billion people classified as overweight or obese in 2013 [2]. Obesity is associated with an increased risk of cardiovascular disease, type 2 diabetes, cancer, asthma, and osteoarthritis [3]. Epidemiological studies have also highlighted the relationship between general bone

Vanessa Nicolin

nicolin@units.it

1 Bone Laboratory, Department of Medical, Surgical and Health Sciences, University of Trieste, Ospedale Maggiore, Piazza Ospitale 1, 34100 Trieste, Italy

2 School of Dental Sciences, Department of Medical, Surgical and Health Sciences, University of Trieste, Trieste, Italy and periodontal diseases and obesity $[4,5]$, probably mediated by lipoinflammation, indicating that obesity is second only to smoking as a risk factor for the perturbation of inflammatory periodontal tissues [6].

Lipoinflammation is a relatively new word, and it has recently been reported to be involved also in a part of pathogenesis of obesity-induced non-alcoholic fatty liver disease (NAFLD) [7]. Adipose tissue is a metabolically active endocrine tissue whose functions include the following: (I) the maintenance of the energy balance; (II) thermoregulation; (III) the metabolism of lipids and glucose; (IV) modulation of hormonal and reproductive function; and regulation of (V) blood pressure and of (VI) blood coagulation. In addition, it plays a fundamental role on inflammatory, antifibrinolytic, and vasoactive cascades, suggesting a possible influence on the inflammatory process $[8,9]$. In particular, in conditions of overweight, it has been demonstrated that approximately 70 $80 \%$ of individuals present an adipose tissue turnover that is both structurally and functionally causing of the systemic inflammatory reaction [10]. With the aim to clarify the relationship between adipose tissue inflammation and bone, the 
authors will treat the topic of the adipose tissue and its impact on the inflammatory pathologies like periodontal disease.

\section{Adipose Tissue and the "Lipoinflammation" Concept}

Adipose tissue is composed by adipocytes, preadipocytes, endothelial cells, pericytes, fibroblasts, mast cells, and immune cells (macrophages and T lymphocytes). Its employ has autocrine, endocrine, and paracrine functions on the rest of the organs through the secretion of a wide variety of enzymes, growth factors, hormones, and cytokines, which induce the activation of specific receptors localized on cell membranes, cell proliferation, and differentiation functions. As known, cytokines that are involved in modulating physiological responses in charge of adipose tissue are called adipocytokines $[9,11]$, so leptin, adiponectin, and tumor necrosis factor alpha $(\mathrm{TNF} \alpha)$ are called some of the most important adipocytokines $[12,13]$. When there is a positive energy balance, the energy surplus accumulates in the subcutaneous adipose tissue. This is increasing due to hyperplasia, that is, from the proliferation and differentiation of pre-adipocytes. When the subcutaneous adipose tissue is unable to properly store excess energy or the storage has been exceeded, visceral fat deposits increase, which loses adipogenic capacity due to hypertrophy that is characterized by increase in size of adipocytes. Therefore, in conditions of obesity, the increase due to hyperplasia has been associated with the dysregulation of adipose tissue that entails a remodeling of its structure, and subsequent chronic inflammation starts involving inflammatory cell infiltration and activation of the cytokine network [14-16]. At the microscopic level, obese adipose tissue exposed cells to stressful conditions, including hypoxia, oxidant stress, and endoplasmic reticulum stress (ER stress) (Fig. 1). Certain physiological and pathological factors such as nutrient deprivation and lipids can induce cell stress and disrupt ER homeostasis by promoting unfolded protein overload. The perturbation/stress of the ER compartment is defined as the accumulation of unfolded proteins in ER lumen that leads to the unfolded protein response (UPR) that is involved in the mediation of a cascade of inflammatory responses. Probably, ER stress can directly initiate inflammatory pathways such as pro-inflammatory stimuli; i.e., TLR ligands and cytokines that result in a UPR activation can further amplify inflammatory responses [17]. As described in Fig. 1, ER stress activates pro-inflammatory pathways by two different ways:

(a) By the activation of ATF6 (activating transcription factor 6 is a protein involved in the unfolded protein response).

(b) By the interaction of IRE alpha (inositol-requiring enzyme 1 alpha).

All ways result in the activation of proinflammatory factors (NF-KB) that results as an enhancement of the inflammatory reaction.

Many processes directly related to adipocyte hypertrophy have been described. Studies in animals and also in humans have shown that hypoxia (poorly oxygenated adipose tissue) appears in the first stages of hypertrophic adipose tissue expansion. In these areas of adipose tissue, the secretion of proinflammatory adipocytokines such as macrophage migration inhibitor factor (MIF), metalloproteinase matrix (MMP2 and MMP9), interleukin 6 (IL-6), plasminogen activator inhibitor1 (PAI-1), and vascular endothelial growth (VEGF), has been observed. In a parallel manner, the lower level of oxygenation is linked to the apoptosis of the adipocytes that results as an enhancement of the inflammatory reaction.

\section{Obesity and Periodontal Disease}

Adipose tissue inflammation is a major characteristic of dietinduced obesity and is a critical link between obesity and the development of insulin resistance.

Periodontitis is an inflammatory disease that involves progressive reduction of alveolar bone around the teeth and can

Fig. 1 Schematic pattern of inflammation correlated to

VASCULAR HEMOSTASIS, PROMOTERS OF ANGIOGENESIS obesity

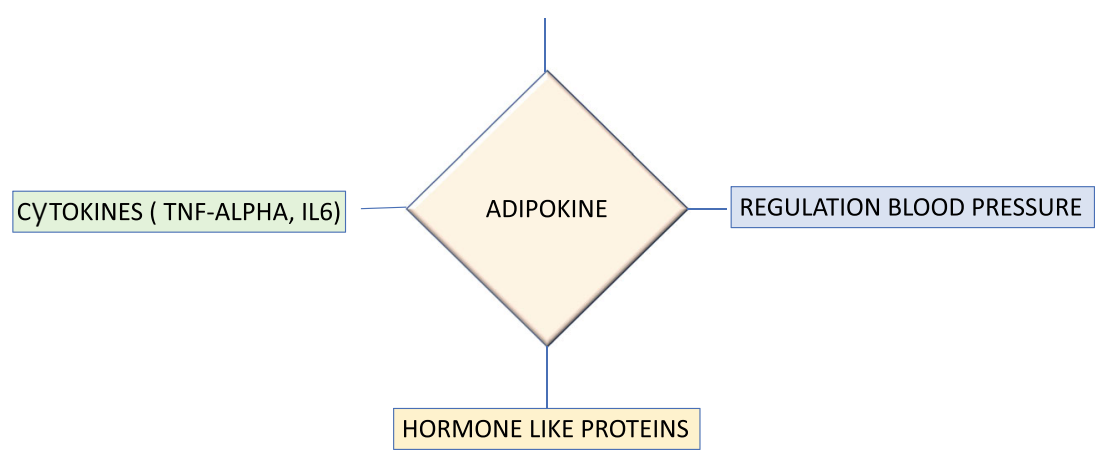


result in tooth loss. Several mechanisms have linked adipose tissue accumulation and alveolar bone deterioration, including (I) increased gingival oxidative stress [18], (II) adipocyte differentiation in detrimental osteoblast formation, (III) local dysbiosis favoring periodontopathogens [19], (IV) local and/ or systemic increase of receptor activation of NF-kappaB ligand (RankL) [20], (V) release of proinflammatory cytokines and adipokines [21], and (VI) the direct influence of bone marrow-driven adipocytes on osteoclast formation via RANKL cell-to-cell contact [22].

Increased body of evidence has highlighted a correlation between obesity and periodontal disease, as reported by 14 systematic reviews published between 2010 and 2014 [4, 5, 23-34].

Moreover, a recent meta-review by Suvan and coworkers highlighted different levels of correlation, useful for clinical application of the growing body of knowledge [35]. The results of meta-review underline how obese patients are more prone to have a certain form of periodontitis than normal weight patients (without any correlation with gender or age). Moreover, there was found a linear proportionality between weight and severity of periodontal disease. Secondly, the likelihood of onset and progression of periodontal disease appears increased in overweight population. Conversely, there is still no agreement in therapy response: indeed, five included reviews that reported no differences in clinical response to causal therapy; otherwise, one reported a scarcer response. A cross-sectional study reported also the amount of correlation, with a 1.45 of relative risk for obese population for attachment loss [36]. As for other systemic pathologic condition such linked to inflammation as cardiovascular disease, the correlation is bimodal once periodontal disease is present, and the burden of local infection and inflammation stimulates the hepatic response through the increase of dissemination of bacteria and their products together with cytokines and reactive oxygen species [35]. The authors underline, however, that the knowledge of this correlation is still lacking of elements that may help the clinical management of these two chronic conditions such as the exact odd and the role of the treatment of one to the other.

\section{Bone Fat and Skeletal Turnover}

Adipose tissue is a metabolically active tissue with endocrine effects. It produces cytokines and adipokines that may influence the activity of other tissues [37-39].

Many authors underlined the possible role of the adipose tissue excess and skeletal turnover [40] that can be summarized in (I) endocrine and growth factors released by adipocyte cells with a direct effect on osteoblast and osteoclast cells; (II) adipokines (e.g., leptin and adiponectin) regulate central nervous system release of factors from the sympathetic nervous system; and (III) paracrine factors secreted by adipocytes inside the blood circulation acting on monocyte recruitment (Fig. 2). Of note, there are many controversial visions about the effect of adiponectin on skeletal system; many authors clarify the role of adiponectin that regulates bone turnover acting on the stimulation of osteoclast compartment [41], promoting osteoblast cell proliferation and differentiation probably acting on RANKL expression at the same time by the inhibition of osteoprotegerin expression. Meanwhile, other authors like Qisheng et al. and Oshima et al. reported that

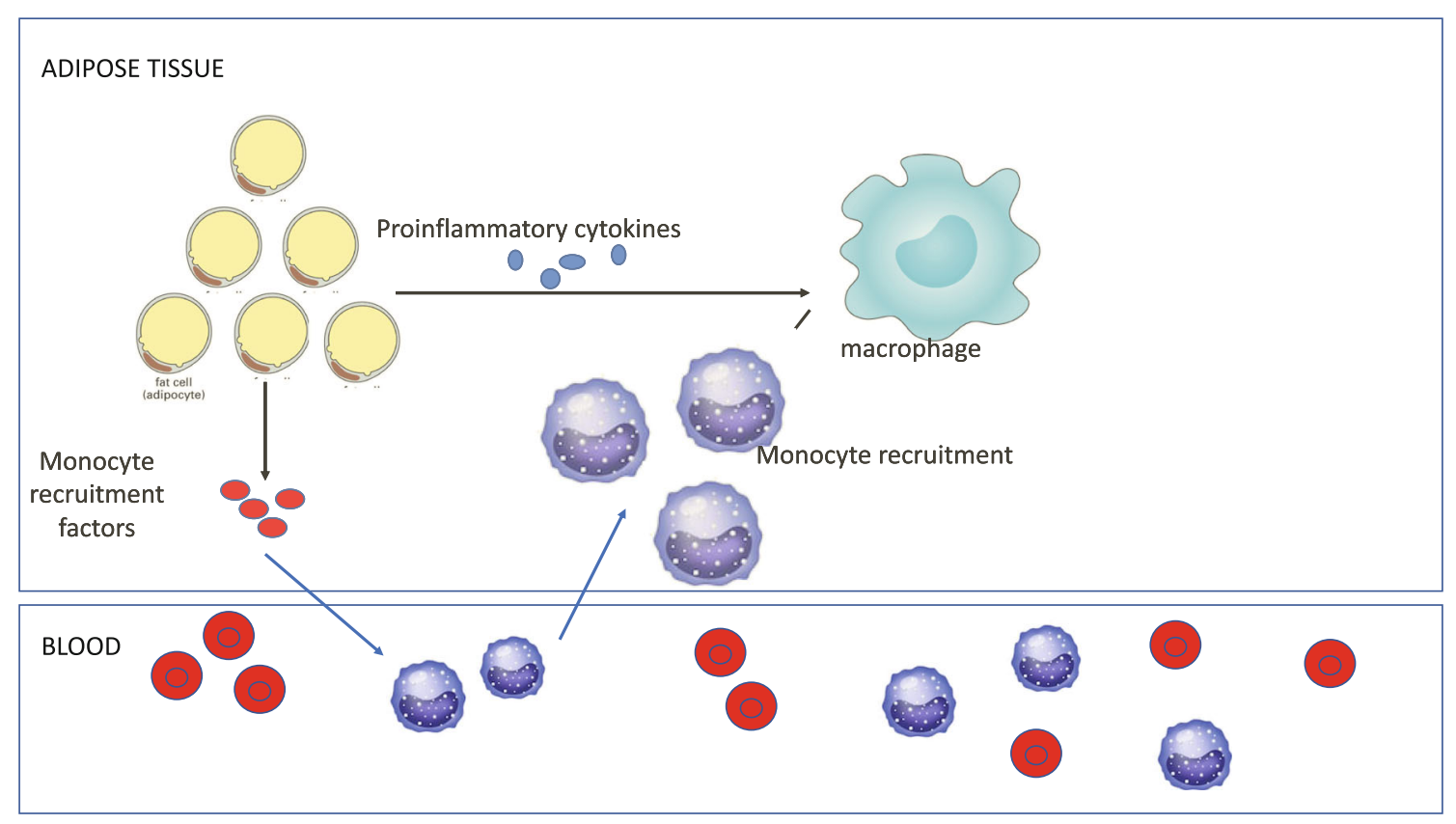

Fig. 2 Schematic pattern of monocyte recruitment induced by adipocyte-mediated cytokines 
adiponectin decreased osteoclasts while increasing osteoblasts $[42,43]$. Therefore, given this controversy in cell-type stimuli, other in vitro and clinical studies are needed to clarify the promoting function of adiponectin. In addition to adipocytes, vascular endothelial cells, vascular smooth muscle cells, and fat tissue are histologically characterized by adipose-derived stem/stromal cells (ASCs). ASCs could differentiate into adult adipocytes or, under the suitable stimuli, into pre-osteoblasts. This common fate is controlled by a complex process that includes many factors such as Runx2 (Runt-related transcription factor 2) and osterix for osteoblast lineage and PPAR2 (peroxisome proliferator-activated receptor 2) for adipocyte lineage and osteoclast lineage. Indeed, there are many evidences that indicate PPAR2 as involved in osteoclast differentiation probably acting on the employment of the coactivator of (peroxisome proliferator activated receptor gamma 2) PPARG2 known as PGC-1beta (peroxisome proliferatoractivated receptor gamma, coactivator 1 beta) factor that is directly connected to the expression of RANKL (receptor activator of nuclear factor kappa-B ligand). The negative correlation between marrow fat and bone mass could be due to increasing levels of PPARG2 [44]. High levels of PPARG2 within the bone marrow are followed by a predominant differentiation of MSC into adipocytes with a potential lipotoxic effect. A fascinating liaison is constituted by the release of leptin (adipocyte made) and metabolic homoeostasis [45, 46] that ultimately could have a reflection on the bone turnover. Some authors [47] suggest that leptin acting on central nervous system, by the activity on the ventromedial hypothalamus, plays a role into the inhibition of bone mass [48] but it seems to be related by a dose-dependent correlation [49].

When the metabolic homeostasis is altered for the pathological expansion of adipose tissue, the consequent adipocyte hypertrophy is associated with cell hypoxia and activation of cellular stress signaling including c-Jun N-terminal kinase (JNK), nuclear factor-kappa B (NF-kB), and proteins related with stress response [50-52]. These factors result in an overexpression of inflammatory cytokines that acting on inflammatory macrophage colonize the adipose tissue activating a program of inflammation of neighboring cells. Recent studies showed that body fat accumulation increases bone resorption [53, 54] probably acting on receptor activator of nuclear factor-kappaB ligand (RANKL) pathway. Indeed, the high-fat diet is implicated in the control of some inflammatory genes, i.e., Tnsf1/ RANKL that represents a crossroad between immune feedback and osteoclast recruitment finalized to bone remodeling.

\section{Adiponectin and Bone Loss Related to Periodontal Disease}

The reduction of bone mass with obesity may be due to enhancement marrow adipogenesis at the detriment of osteoblasts, and/or increased osteoclast formation caused by the overexpression in terms of proinflammatory cytokines, and/or excessive leptin release, or downregulation of adiponectin expression, and/or diminished calcium absorption associated with high-fat consumption. Many authors indicate that adiponectin increases osteoclast formation indirectly stimulating RANKL and inhibiting OPG (osteoprotegerin) production in osteoblasts, which may unfavorably affect bone metabolism, and contribute to the negative effect of adiponectin on bone mineral density (BMD) [41]. Adiponectin is mainly produced by adipocytes, and its serum level production has found to be decreased in the case of obesity [55]. A recent investigation evaluated the impact of weight reduction on the adipokine, adiponectin, and TNF- $\alpha$ levels in the crevicular fluid and on the periodontal health of obese patients with and without periodontal disease [56]. The patients were divided in three groups according to the periodontal status: (I) healthy; (II) gingivitis; (III) periodontitis. All the patients enrolled underwent a weight loss program. Statistically significant changes were observed in the plasma levels of adiponectin and TNF $\alpha$ in all three groups before and after weight reduction. The serum adiponectin levels showed an increase in the levels following weight reduction, whereas TNF $\alpha$ levels decreased following weight reduction, confirming previous findings [55]. Madsen et al. reported that long-term weight loss (3 years) must exceed 10\% for achieving significant improvements in adiponectin levels [57]. A negative feedback might explain the role of adiponectin: in obesity, serum adiponectin is lower despite that adipose tissue is the only tissue of its synthesis. Weight loss would result in at least transient disinhibition, therefore an increase of plasma adiponectin. In fact, a recent study has reported that the expression of adipogenic genes was suppressed in the development of obesity and diabetes in mice for a feedback inhibitory pathway [58]. Similarly, to periodontal disease correlation, a recent study found association between adiponectin and rheumatoid arthritis. These two chronic diseases encounter a common inflammatory pathway. As such, the authors suggest an association between an excess of adipose tissue and the initiation of rheumatoid arthritis by the potential role of the adipose tissue as an active endocrine organ that releases bioactive substances, such as adiponectin [59]. However, both for periodontal disease and rheumatoid arthritis, the scientific evidence is still limited. Further prospective studies should be conducted with molecular evaluation of serum and crevicular fluid to better understand the role of this inflammatory cytokine in the modulation of periodontal disease.

\section{Conclusions}

The present study may help to elucidate the roles played by lipoinflammation and obesity in biochemical trafficking inside inflamed periodontal tissues. These links could affect 
the clinical manifestation, progression, and prognosis of periodontal disease. Therefore, the oral care team should interact with other medical professionals to better manage a tailored treatment for the patients transferring the common pattern of these two diseases. Further investigations are, however, still needed mostly to understand the possible role of non-surgical periodontal therapy in the obesity treatment and vice versa.

Code Availability Not applicable.

Authors' Contributions Nicolin Vanessa: article writing and revision Costantinides Fulvia: research protocol definition and article writing Berton Federico: article writing and revision

Vettori Erica: article writing

Marchesi Giulio: article writing

Rizzo Roberto: article writing

Di Lenarda Roberto: article revision

Funding Information Open access funding provided by Università degli Studi di Trieste within the CRUI-CARE Agreement.

Data Availability Not applicable.

\section{Compliance with Ethical Standards}

Conflict of Interest The authors declare that they have no conflict of interest.

Ethics Approval Not applicable.

Consent to Participate Not applicable.

\section{Consent for Publication Not applicable.}

Study on Animals and Human The article does not contain any studies with human or animal subjects performed by the any of the authors.

Open Access This article is licensed under a Creative Commons Attribution 4.0 International License, which permits use, sharing, adaptation, distribution and reproduction in any medium or format, as long as you give appropriate credit to the original author(s) and the source, provide a link to the Creative Commons licence, and indicate if changes were made. The images or other third party material in this article are included in the article's Creative Commons licence, unless indicated otherwise in a credit line to the material. If material is not included in the article's Creative Commons licence and your intended use is not permitted by statutory regulation or exceeds the permitted use, you will need to obtain permission directly from the copyright holder. To view a copy of this licence, visit http://creativecommons.org/licenses/by/4.0/.

\section{References}

1. Pi-Sunyer FX, Becker DM, Bouchard C, Carleton RA, Colditz GA, Dietz WH, et al. Clinical guidelines on the identification, evaluation, and treatment of overweight and obesity in adults: executive summary. Am J Clin Nutr. 1998;68(4):899-917. https://doi.org/10. 1093/ajen/68.4.899.
2. Ng M, Fleming T, Robinson M, Blake T, Graetz N, Margono C, et al. Global, regional, and national prevalence of overweight and obesity in children and adults during 1980-2013: a systematic analysis for the Global Burden of Disease Study 2013. Lancet. 2014;384(9945):766-81. https://doi.org/10.1016/s0140-6736(14) 60460-8.

3. Guh DP, Zhang W, Bansback N, Amarsi Z, Laird Birmingham C, Anis $\mathrm{AH}$. The incidence of co-morbidities related to obesity and overweight: a systematic review and meta-analysis. BMC Public Health. 2009;9:88. https://doi.org/10.1186/1471-2458-9-88.

4. Chaffee BW, Weston SJ. Association between chronic periodontal disease and obesity: a systematic review and meta-analysis. J Periodontol. 2010;81(12):1708-24. https://doi.org/10.1902/jop. 2010.100321.

5. Suvan J, D'Aiuto F, Moles DR, Petrie A, Donos N. Association between overweight/obesity and periodontitis in adults. A systematic review. Obes Rev. 2011;12(5):e381-404. https://doi.org/10. 1111/j.1467-789X.2010.00808.x.

6. Nishida N, Tanaka M, Hayashi N, Nagata H, Takeshita T, Nakayama K, et al. Determination of smoking and obesity as periodontitis risks using the classification and regression tree method. J Periodontol. 2005;76(6):923-8. https://doi.org/10.1902/jop.2005. 76.6.923.

7. Ishitaq SM, Rashid H, Hussain Z, Arshad MI, Khan JA. Adiponectin and PAAR: a setup for intricate crosstalk between obesity and non-alcoholic fatty liver disease. Rev Endocr Metab Disord. 2019;20(3):253-61. https://doi.org/10.1007/s11154-01909510-2.

8. Rodriguez-Rodriguez E, Perea JM, López-Sobaler AM, Ortega RM. Obesity, insulin resistance and increase in adipokines levels: importance of the diet and physical activity. Nutr Hosp. 2009;24(4): 415-21.

9. Flores-Lázaro JR, Rodríguez-Martínez E, Rivas-Arancibia S. Metabolic consequences of the functional alterations of adipose tissue in obese patients. Rev Med Hosp Gen Méx. 2011;74(3): 157-65.

10. Kim S, Moustaid-Moussa N. Secretory, endocrine and autocrine/ paracrine function of the adipocyte. J Nutr. 2000;130(12):S3110-5. https://doi.org/10.1093/jn/130.12.3110S.

11. Ibrahim MM. Subcutaneous and visceral adipose tissue: structural and functional differences. Obes Rev. 2010;11(1):11-8. https://doi. org/10.1111/j.1467-789x.2009.00623.x.

12. De Luis DA, González Sagrado M, Conde R, Aller R, Izaola O, Castro MJ. Circulating adipocytokines in morbid obese patients, relation with cardiovascular risk factors and anthropometric parameters. Nutr Hosp. 2011;26(1):91-6.

13. De Luis DA, Aller R, Izaola O, Ovalle HF. The serum profile of adipokines in naïve patients with diabetes mellitus type 2 and obesity. J Clin Lab Anal. 2011;25(6):409-13. https://doi.org/10.1002/ jcla.20493.

14. Wellen KE, Hotamisligil GS. Obesity-induced inflammatory changes in adipose tissue. J Clin Invest. 2003;112(12):1785-8. https://doi.org/10.1172/jci20514.

15. Nishimura S, Manabe I, Nagasaki M, Seo K, Yamashita H, Hosoya $\mathrm{Y}$, et al. In vivo imaging in mice reveals local cell dynamics and inflammation in obese adipose tissue. J Clin Invest. 2008;118:710 21. https://doi.org/10.1172/jci33328.

16. $\mathrm{Xu} \mathrm{H}$, Barnes GT, Yang Q, Tan G, et al. Chronic inflammation in fat plays a crucial role in the development of obesity-related insulin resistance. J Clin Invest. 2003;112(12):1821-30. https://doi.org/10. 1172/jci19451.

17. Zhang K, Shen X, Wu J, Sakaki K, Saunders T, Rutkowski DT, et al. Endoplasmic reticulum stress activates cleavage of CREBH to induce a systemic inflammatory response. Cell. 2006;124(3):58799. https://doi.org/10.1016/j.cell.2005.11.040. 
18. Mizutani K, Park K, Mima A, Katagiri S, King GL. Obesityassocitated gingival vascular inflammation and insulin resistance. J Dent Res. 2014;93(6):596-601. https://doi.org/10.1177/ 0022034514532102.

19. Watanabe K, Iizuka T, Adeleke A, Pham L, Shlimon AE, Yasin M, et al. Involvement of toll-like receptor 4 in alveolar bone loss and glucose homeostasis in experimental periodontitis. J Periodontal Res. 2011;46(1):21-30. https://doi.org/10.1111/j.1600-0765.2010. 01304.x.

20. Cunha JS, Ferreira VM, Naves MA, Boim MA. Effects of high glucose and high insulin concentrations on osteoblast function in vitro. Cell Tissue Res. 2014;358(1):249-56. https://doi.org/10. 1007/s00441-014-1913-x.

21. Zhang L, Meng S, Tu Q, Yu L, Tang Y, Dard MM, et al. Adiponectin ameliorates experimental periodontitis in dietinduced obesity mice. PLoS One. 2014;9(5):e97824. https://doi. org/10.1371/journal.pone.0097824.

22. Goto H, Hozumi A, Osaki M, Fukushima T, Sakamoto K, Yonekura A, et al. Primary human bone marrow adipocytes support TNF- $\alpha$-induced osteoclast differentiation and function through RANKL expression. Cytokine. 2011;56(3):662-8. https://doi.org/ 10.1016/j.cyto.2011.09.005.

23. Akram Z, Abduljabbar T, Abu Hassan MI, Javed F, Vohra F. Cytokine profile in chronic periodontitis patients with and without obesity: a systematic review and meta-analysis. Dis Markers. 2016;2016:1-12. https://doi.org/10.1155/2016/4801418.

24. Akram Z, Safii SH, Vaithilingam RD, Baharuddin NA, Javed F, Vohra F. Efficacy of non-surgical periodontal therapy in the management of chronic periodontitis among obese and non-obese patients: a systematic review and meta-analysis. Clin Oral Investig. 2016;20(5):903-14. https://doi.org/10.1007/s00784-016-1793-4.

25. Gerber FA, Sahrmann P, Schmidlin OA, Heumann C, Beer JH, Schmidlin PR. Influence of obesity on the outcome of nonsurgical periodontal therapy - a systematic review. BMC Oral Health. 2016;16(1):90. https://doi.org/10.1186/s12903-016-02722 .

26. Keller A, Rohde JF, Raymond K, Heitmann BL. Association between periodontal disease and overweight and obesity: a systematic review. J Periodontol. 2015;86(6):766-76. https://doi.org/10.1902/ jop.2015.140589.

27. Li LW, Wong HM, Sun L, Wen YF, McGrath CP. Anthropometric measurements and periodontal diseases in children and adolescents: a systematic review and meta-analysis. Adv Nutr. 2015;6(6):82841. https://doi.org/10.3945/an.115.010017.

28. Martens L, De SS, Yusof MY, Rajasekharan S. Association between overweight/obesity and periodontal disease in children and adolescents: a systematic review and meta-analysis. Eur Arch Paediatr Dent. 2017;18(2):69-82. https://doi.org/10.1007/s40368017-0272-1.

29. Martinez-Herrera M, Silvestre-Rangil J, Silvestre FJ. Association between obesity and periodontal disease. A systematic review of epidemiological studies and controlled clinical trials. Med Oral Patol Oral Cir Bucal. 2017;22(6):e708-15. https://doi.org/10. 4317/medoral.21786.

30. De Moura-Grec PG, Marsicano JA, Paz de Carvalho CA, SalesPeres SH. Obesity and periodontitis: systematic review and metaanalysis. Cien Saude Colet. 2014;19(6):1763-72. https://doi.org/ 10.1590/1413-81232014196.13482013.

31. Nascimento GG, Leite FR, Conceicao DA, Ferrua CP, Singh A, Demarco FF. Is there a relationship between obesity and tooth loss and edentulism? A systematic review and meta-analysis. Obes Rev. 2016;17(7):587-98. https://doi.org/10.1111/obr.12418.

32. Nascimento GG, Leite FR, Correa MB, Peres MA, Demarco FF. Does periodontal treatment have an effect on clinical and immunological parameters of periodontal disease in obese subjects? A systematic review and meta-analysis. Clin Oral Investig. 2016;20(4):639-47. https://doi.org/10.1007/s00784-015-1678-y.

33. Nascimento GG, Leite FR, Do LG, et al. Is weight gain associated with the incidence of periodontitis? A systematic review and metaanalysis. J Clin Periodontol. 2015;42(6):495-505. https://doi.org/ 10.1111/jcpe. 12417.

34. Papageorgiou SN, Reichert C, Jager A, Deschner J. Effect of overweight/obesity on response to periodontal treatment: systematic review and a meta-analysis. J Clin Periodontol. 2015;42(3):247-61. https://doi.org/10.1111/jcpe.12365.

35. Suvan JE, Finer N, D'Aiuto F. Periodontal complications with obesity. Periodontol 2000. 2018;78(1):98-128. https://doi.org/10. 1111/prd.12239.

36. Nascimento GG, Peres KG, Mittinty MN, Mejia GC, Silva DA, Gonzalez-Chica D, et al. Obesity and periodontal outcomes: a population-based cohort study in Brazil. J Periodontol. 2017;88(1):50-8. https://doi.org/10.1902/jop.2016.160361.

37. Reid IR. Fat and bone. Arch Biochem Biophys. 2010;503(1):20-7. https://doi.org/10.1016/j.abb.2010.06.027.

38. Neumann T, Lodes S, Kästner B, Franke S, Kiehntopf M, Lehmann $\mathrm{T}$, et al. Osteocalcin, adipokines and their associations with glucose metabolism in type 1 diabetes. Bone. 2016;82:50-5. https://doi.org/ 10.1016/j.bone.2015.04.017.

39. Kajimura D, Lee HW, Riley KJ, Arteaga-Solis E, Ferron M, Zhou $\mathrm{B}$, et al. Adiponectin regulates bone mass accrual through two opposite mechanisms, one local and one central, that both rely on FoxO1. Cell Metab. 2013;17(6):901-15. https://doi.org/10.1016/j. cmet.2013.04.009.

40. Kawai M, De Paula FJA, Rosen CJ. New insights into osteoporosis: the bone-fat connection. J Intern Med. 2012;272(4):317-29. https:// doi.org/10.1111/j.1365-2796.2012.02564.X.

41. Luo XH, Guo LJ, Xie H, Yuan LQ, Wu XP, Zhou HD, et al. Adiponectin stimulates RANKL and inhibits OPG expression in human osteoblasts through the MAPK signaling pathway. J Bone Miner Res. 2006;21(10):1648-56. https://doi.org/10.1359/jbmr. 060707.

42. Tu Q, Zhang J, Dong LQ, Saunders E, Luo E, Tang J, et al. Adiponectin inhibits osteoclastogenesis and bone resorption via APPL1-mediated suppression of Akt1. J Biol Chem. 2011 Apr 8;286(14):12542-53. https://doi.org/10.1074/jbc.m110. 152405.

43. Oshima K, Nampei A, Matsuda M, Iwaki M, Fukuhara A, Hashimoto J, et al. Adiponectin increases bone mass by suppressing osteoclast and activating osteoblast. Biochem Biophys Res Commun. 2005;331(2):520-6. https://doi.org/10.1016/j.bbrc. 2005.03.210.

44. De Pablo P, Chapple IL, Buckley CD, Dietrich T. Periodontitis in systemic rheumatic diseases. Nat Rev Rheumatol. 2009;5(4):218 24. https://doi.org/10.1038/nrrheum.2009.28.

45. Ahima RS, Osei SY. Leptin signaling. Physiol Behav. 2004;81(2): 223-41. https://doi.org/10.1016/j.physbeh.2004.02.014.

46. Myers MG, Cowley MA, Munzberg H. Mechanisms of leptin action and leptin resistance. Annu Rev Physiol. 2008;70:537-56. https://doi.org/10.1146/annurev.physiol.70.113006.100707.

47. Stunes AK, Westbroek I, Gordeladze JO, Gustafsson BI, Reseland JE, Syversen U. Systemic leptin administration in supraphysiological doses maintains bone mineral density and mechanical strength despite significant weight loss. Endocrinology. 2012;153(5):2245-53. https://doi.org/10.1210/en.2011-1848.

48. Takeda S, Elefteriou F, Levasseur R, Liu X, Zhao L, Parker KL, et al. Leptin regulates bone formation via the sympathetic nervous system. Cell. 2002;111(3):305-17. https://doi.org/10.1016/s00928674(02)01049-8.

49. Cirmanová V, Bayer M, Stárka L, Zajícková K. The effect of leptin on bone: an evolving concept of action. Physiol Res. 2008;57(Suppl 1):S143-51. 
50. Chawla A, Nguyen KD, Goh YP. Macrophage-mediated inflammation in metabolic disease. Nat Rev Immunol. 2011;11(11):73849. https://doi.org/10.1038/nri3071.

51. Gregor MF, Hotamisligil GS. Inflammatory mechanisms in obesity. Annu Rev Immunol. 2011;29(1):415-45. https://doi.org/10.1146/ annurev-immunol-031210-101322.

52. Shoelson SE, Lee J, Goldfine AB. Inflammation and insulin resistance. J Clin Invest. 2006;116(7):1793-801. https://doi.org/10. 1172/JCI29069.

53. Yasuda H, Shima N, Nakagawa N, Yamaguchi K, Kinosaki M, Mochizuki S, et al. Osteoclast differentiation factor is a ligand for osteoprotegerin/osteoclastogenesis-inhibitory factor and is identical to TRANCE/RANKL. Proc Natl Acad Sci. 1998;95(7):3597-602. https://doi.org/10.1073/pnas.95.7.3597.

54. Anderson DM, Maraskovsky E, Billingsley WL, Dougall WC, Tometsko ME, Roux ER, et al. A homologue of the TNF receptor and its ligand enhance T-cell growth and dendritic-cell function. Nature. 1997;390(6656):175-9. https://doi.org/10.1038/36593.

55. Nigro E, Scudiero O, Monaco ML, Palmieri A, Mazzarella G, Costagliola C, et al. New insight into adiponectin role in obesity and obesity-related diseases. Biomed Res Int. 2014;2014:6589134. https://doi.org/10.1155/2014/658913.

56. Vivekananda L, Faizuddin M. Effect of weight reduction on the serum adiponectin and tumor necrosis factor- $\alpha$ levels and the clinical parameters of obese patients with and without periodontal disease. J Int Soc Prev Community Dent. 2019;9(2):166-71. https:// doi.org/10.4103/jispcd.jispcd_447_18.

57. Madsen EL, Rissanen A, Bruun JM, Skogstrand K, Tonstad S, Hougaard DM, et al. Weight loss larger than $10 \%$ is needed for general improvement of levels of circulating adiponectin and markers of inflammation in obese subjects: a 3 year weight loss study. Eur J Endocrinol. 2008;158(2):179-87. https://doi.org/10. 1530/eje-07-0721.

58. Yang WS, Lee WJ, Funahashi T, Tanaka S, Matsuzawa Y, Chao $\mathrm{CL}$, et al. Weight reduction increases plasma levels of an adiposederived anti-inflammatory protein, adiponectin. J Clin Endocrinol Metab. 2001;86(8):3815-9. https://doi.org/10.1210/jcem.86.8. 7741.

59. Chaparro-Sanabria JA, Bautista-Molano W, Bello-Gualtero JM, Chila-Moreno L, Castillo DM, Valle-Oñate R, et al. Association of adipokines with rheumatic disease activity indexes and periodontal disease in patients with early rheumatoid arthritis and their firstdegree relatives. Int J Rheum Dis. 2019;22(11):1990-2000. https:// doi.org/10.1111/1756-185X.13724.

Publisher's Note Springer Nature remains neutral with regard to jurisdictional claims in published maps and institutional affiliations. 